Ilmu Dakwah: Academic Journal for Homiletic Studies

Volume 14 Nomor 2 (2020) 187-210

DOI: $10.15575 /$ idajhs.v14i2. 10219

http://journal.uinsgd.ac.id/index.php/idajhs

ISSN 1693-0843 (Print) ISSN 2548-8708 (Online)

\title{
Pluralistic Da'wah Model in Maintaining Religious Tolerance in Bekasi
}

\author{
Deden Sumpena $^{1 *} \&$ Adon Nasurullah Jamaludin ${ }^{2}$ \\ ${ }^{12}$ Universitas Islam Negeri Sunan Gunung Djati Bandung, Indonesia \\ * email. dedensumpena67@gmail.com
}

\begin{abstract}
This article aims to explore the perceptions of religious pluralism, identify the models of da'wah, and describe the community's efforts to build harmony in Kampung Sawah, Bekasi. This study uses a qualitative descriptive method. From the results of the study it can be explained that the community interprets pluralism as an awareness of mutual respect. There are three models of da'wah being implemented in Kampung Sawah which include wise da'wah, transformative da'wah, inclusive da'wah. Meanwhile, the community maintain harmony in Kampung Sawah by avoiding conflict, promoting dialogue, mutual cooperation, and holding the Ngariung Bareng: Forum.
\end{abstract}

Keyword: Da'wah; tolerance; pluralistic.

\begin{abstract}
ABSTRAK
Artikel ini bertujuan menggali persepsi pluralisme agama, mengidentifikasi model dakwah yang dilakukan, dan mendeskripsikan upaya masyarakat dalam membangun kerukunan di Kampung Sawah. Penelitian ini menggunakan metode deskriptif kualitatif Dari hasil penelitian dapat dijelaskan, bahwa masyarakat memaknai pluralisme sebagai kesadaran saling menghargai. Terdapat tiga model dakwah yaitu; dakwah yang arif, dakwah transformatif dan dakwah inklusif. Sedangkan upaya masyarakat dalam menjaga kerukunan, yaitu dengan menghindari konflik, Dialog, Gotong Royong, dan menyelenggarakan Forum Ngariung Bareng.
\end{abstract}

Kata kunci : Dakwah; toleransi; pluralistik

\section{INTRODUCTION}

Da'wah in a society with homogeneous religion will be easy to be done and will not face many obstacles. However, da'wah in a heterogeneous and 
plural society, with diverse religions, is different. The da'wah must ensure that the messages are conveyed to the target and in the same time shuld maintain the harmony in the community. So the preachers (da'i, mubalig, kiai, ustad, ajengan) have a very important duty and role in order to build discourses between these different people. In this position, preachers must be able to establish themselves the link between the two religions, which can bridge the interests of society, especially creating and maintaining harmony and tolerance in society.

Carrying da'wah in a diverse society as above requires model that is different from that in a region with homogeneous religiously. In a religiously heterogeneous region, da'wah activities may cause suspicion and misunderstanding that may turn to religious conflict. Therefore, da'wah in a heterogeneous society is rather not easy to do and requires bold and correct strategy. However, it doesn't mean that it cannot be done. To be able to do it, a preacher would need a comprehensive knowledge and understanding regarding the social context of the community as well as knowledge on the appreciation and practice of the teachings of the two religions in the location. These knowledge and understanding would be very useful in responding to the problem of plurality of the society in various aspects which have recently been torn apart in conflicts.

Bekasi City is one of the cities with heterogeneous communities. Since 1996, some part of Bekasi Regency has been transformed into a Municipality (Kotamadya), and has continued to develop as a City. In its relatively young age (16 years), the city has become a very diverse city in terms of culture, ethnic, race, and religion. This is due to social changes marked by industrialization (changes in agricultural areas to industrial estates), and then the urbanization process (migration from villages to cities) (Asy'ari, 1993: 62). Furthermore, the changes that occurred in Bekasi City have given birth to a city modernization process (the process of transforming traditional values into modern structures and values) (Suwarsono, 2006: 23). Such transformation resulted in changes in norms, values, attitudes, behavior, and patterns of life in society (Soemardjan \& Soemardi, 1974: 487).

Bekasi city can be categorized as urban area. The complexity of the urban area has created several challenges such as the reduced locality and the increase of heteregenity; various religions and places of worship; the change of lifestyle and social systems; changes in land use and reduced land size; high and dense population. All of these are the result of the 
unstoppable urbanization in Bekasi city. In terms of religion, Bekasi is a diverse city. However, its diversity has been challenged by the emergence of conflicts between religious communities, especially conflicts over the construction of worship buildings. In this situation, the da'wah needs to be delivered in wise, transparent, and inclusive way (not exclusive).

One of the areas in Bekasi that caught the writer's attention was Kampung Sawah. This area is located in Jatimurni Village, Pondok Melati District, Bekasi City. For most Bekasi people, Kampung Sawah is known as a pluralistic kampong. Even though inter-religious conflict has happened in some parts of Bekasi, Kampung Sawah has been able to maintain harmony among its different religious believers. Given its diverse religion and strong traditional customs one may think that this area is prone to conflict. However, this is not the case.

With that background, this article aims to; first, knowing the public's perception of pluralism. Second, understanding how the dakwah model is carried out in the area, so that it can properly maintain religious tolerance, and bring about harmony and integration of Muslims in the area. Third, describing how communities in the kampong are building and maintaining harmony.

Some previous studies on pluralistic da'wah have been carried out. First is a study from Muhammad Qadaruddin Abdullah (2019) on Da'wah Strategies in Caring for Plurality among Adolescents. The article, which was written by using literature study, told the story of da'wah among plural youth. The research segment was teenagers. The results of this study indicated that there are three da'wah strategies that can be carried out to maintain plurality values among adolescents which include the da'wah of structure, culture, and new media. Structural da'wah is a da'wah that makes the state and power a tool to fight for the truth. During the time when the Prophet Muhammad preached in Medina, he became a religious leader as well as a state leader. Da'wah in the state is a means of connecting the government and society. Cultural da'wah is using socio-cultural tools to build community morals. Cultural da'wah aims to address cultural differences as one of the obstacles in preaching, especially in plural societies.

With fast information and cultural flow, one way to stem negative cultural influences can be done by strengthening positive culture that in line with Islamic teachings. The intercultural da'wah strategy is an active effort to integrate ideas and da'wah movements by considering the socio-cultural 
diversity in society. Da'wah through new media is a da'wah which is effective for teenagers. Technological developments are followed by changes in people's behavior. New media has contributed to the spread of a variety of negative information. Information that contains slander, hoax, hatespeech, and radical views can be easily accessed by the public. One of ways to tackle this problem is by producing and diseminating positive content in cyberspace through media spiritualization, in which the media is used as a means of da'wah.

The second is Zainol Huda's research (2016) entitled Multicultural Islamic Da'wah. In his writing, Huda presented a historically multicultural portrait of Islamic da'wah, the preaching that was carried out by the Prophet Muhammad SAW, to non-mulsim communities at the beginning of the prophetic period. From the results of his study, it can be concluded that the Prophet used several following methods. First, direct open dialog method. Second, narrative method which narrate the stories of the people in the past. Third, method of analogy that presents the moral qualities and personality of the Prophet as a role model.

The third is Maqbul Arib study (2014) on Da'wah in the Mid of the Diversity and Differences of Muslims. This article also talked about how preachers are doing da'wah in a plural society. The conclusion of this research is that, first, basically Islam is a blessing for all nature. It means that empowerment and improvement of the quality of life as recommended by the Qur'an should be enjoyed by all living things regardless of differences in belief and religion. Therefore, by utilizing the existing potential in a pluralistic world like this, the Islamic da'wah model will be more meaningful once it is carried out by involving all parties including those outside Islam. Second, many things can be done and many problems can be resolved through cooperation between religious communities. Human problems in the modern era, such as poverty and hunger are mainly caused by injustice, economic, social, political exploitation and racial injustice, gender as well as the threat of conflict and ecosystem damage. All these problems can only be resolved through cooperation with the principle of mutual understanding between the people from various religion. Thus, the inevitable plurality, diversity or plurality can be utilized as "social energy".

Even though the three articles above are similar with the author's article in terms issue, they are different from the author's article in from the source and data collection method. They were mostly written based on 
literature review thus relied on information from references on pluralistic societies. In other words, the writings examined pluralist society from theoretical perspective. While the author's article is written based field study, with a focus on the Kampung Sawah area. As a matter of fact, not theory, kampung Sawah is a pluralistic area inhabited by people with different religions. The author examines pluralistic society based on the facts in the field as found in Kampung Sawah, Bekasi city. Thay way, it is expected that this study would be able to understand the real condition of pluralistic society and pluralism that is really exists in society. In addition, the study is also expected to contribute to building knowledge especially on the study of pluralistic theory, which is generated from the field, that in turn would result in new theories or information about the real pluralistic society.

This article is the result of field research using descriptive-qualitative method. The results of this study are described qualitatively based on data collected in the field. Data was collected through observation techniques, in-depth interviews, literature study, and documentation. The data collected from main informants and key informants. The main informants include the Head of the Office of the Ministry of Religious Affairs of Bekasi City. While the key informants consisted of the Head of the Religious Harmony Forum or Forum Kerukunan Umat Beragama (FKUB) at the District level, KUA Pondok Melati District, Jatimurni Village, religious leaders (Kiai, ustad/ustadzah), community leaders, traditional (cultural) leaders, youth and community figures who are relevant with the issue studied in this research. After the data was collected, it went through editing, classification, comparison, then interpretation to get understanding about the data. Further, the understanding was written as research results in descriptive and analytic way that reveal various findings as it stated in the purpose of this research.

\section{RESULT AND DISCUSSION}

\section{The Condition of Community in Kampung Sawah}

Kampung Sawah is one of the kampong in Jatimurni Village, Pondok Melati District, Bekasi City. Kelurahan Jatimurni has 8 RWs, and Kampung Sawah is RW 02 with 7 RTs in it. The population of Kampung Sawah is 3415 individuals with 854 households. Historically, the geographic boundaries of Kampung Sawah has changed from time to time. Initially, it was a hamlet of Jati Ranggon Village (before becoming a kelurahan) and 
later was divided into 3 areas, namely Jatimurni Village, Jatiwarna Village, and Jati Ranggon Village.

Decades ago, this area was known as a forest area. People rarely passed through the area. Its surrounding had the same conditions with the area of Lubang Buaya. In the past, when the PKI Movement of 30 September 1965 killed the Generals, they were banished and put in the Lubang Buaya area, as an area that was difficult for others to find. The purpose of PKI was that the action could not be traced by others.

Transportation back then was very limited. The only transportation mode that can reach Kampung Sawah was horse and it took one day by hourse to get to the kampung. There was only footpath, no asphalt, yet that was very useful for people to walk. People only walked along this path during the day. At night, no one dared to do it. Because of this limited transportation mode and infrastructure, living in Kampung Sawah at that time was like living in an area that was very far from the city. In fact, this area was on the outskirts of Bekasi City and not so far far to the capital city of Jakarta.

In1995s, this area began to be noticed by the local government. The road access to the Kampung was paved with asphalt so that cars could be used (village public transport or angkutan desa and private cars). The kampung has developd from year to year and people came from many areas that made the area increasingly by many residents. Nowadays, this area has become a fairly prosperous, open, and is no longer categorized as a remote area. The life of the people is no different from other kampungs around Jatimurni Village. However, the population is not so prosperous. Based on data available in the Kelurahan Jatimurni, the people of Kampung Sawah are categorized as the recipients of aid or assistance from the government.

Along the main road in Kampung Sawah we can find many luxurious buildings, houses of worship, especially Christian houses of worship, as well as shops and various facilities used by Christians. For example, there are Christian schools (Strada and Catholic schools), health centers (Melani health centers), training centers and with lodging, and peaceful cottage (places for pastors and missionaries training).

All these facilities and infrastructure are belong to the Christian community. In the past, they bought a lot of land from the local people on the side of the road and then they built some facilities including church. It makes it easy for Christians who want to go to the church to do worship. During Sunday worship, many Christians from outside the area come to 
churches Kampung Sawah. So it's no wonder that every day many luxury cars come in and out of the kampung.

However, most of the people of Kampung Sawah have a modest level of economy. Most of them work in small trading, entrepreneurship, and farming. Only a few work as employees or workers in the private sector. Interestingly, among RWs in Kelurahan Jatimurni, Kampung Sawah is the only RW that has a unique (plural) and interesting (tolerant) diversity characteristics, both in terms of its believers and houses of worship.

Demographically, the majority of the population of Kampung Sawah is Muslim and the majority of ethnicity is Betawi. In the past, almost all residents of Kampung Sawah were Muslim. But looking at the contemporary Kampung Sawah, there is an extraordinary and strange phenomenon the writer has captured. There is something unique in the context of Betawi culture. This area is the first Betawi kampung that is inhabited by people of various religions. This symptom is a bit "deviating" from the prevalence of Betawi citizens who are identical to Islam.

The Kampung Sawah is known as the golden triangle area of Islam, Catholicism, and Protestanism. The three religions are united in the life of the people of Kampung Sawah. Each of them walked on its tracks, there was no fuss and no feud between them. The author was amazed that in the kampung there is a large mosque (grand mosque) stands side by side with a large Christian church. The question is, how the da'wah in this kampung being carried out, so that it creates high tolerance among its religious believers.

\section{Religious Pluralisme; Perspective of Islam and Christianity}

Pluralism is the attitude, understanding, and awareness of the reality of plurality, diversity, as a necessity, as well as active participation in promoting its significant meaning in the context of fostering and manifesting the life of the nation and state in a human and dignified direction. In other words, pluralism is the attitude of acknowledging each other's existence with a frame of brotherhood spirit and ensuring the religious freedom of each individual (Wibisono, 2016: 12).

The plurality of religions in Kampung Sawah is indicated by the existence of various places of worship. There are Islam, Catholic, and Protestant, and small proportion of Hindu and Buddhist. Besides the many number of house of worship, the population composition in this area is also balanced between the three religions. 
Religious plurality and harmony is an interesting phenomenon in the kampung. Plurality of religion and religious harmony does not only occur at the community level, but also in the family. In the Kampung Sawah, many families whose members embrace different religions. Despite the diversity, according to residents, conflicts rarely occur. Another informant (AL), told the same story. He said that there has never been no conflict originating on religious issues. It is because people respect each other's beliefs and relgions (Praptanto, 2011).

Furthermore, the harmony in Kampung Sawah is in line with what the people of Kampung Sawah understand that religion for them is a basic life guideline. It means that any religion teaches or contains all good teachings for the safety and welfare of people's lives. In this world, whatever religion is embraced is the same because all religions teach salvation.

Positive attitude of pluralism in the people of Kampung Sawah can be seen from the acceptance of other religions so that they do not force others to follow their religions. They also respect each other's rights and obligations. In addition, collectivity or family attitude (kekeluargaan) is very visible when someone is sick or experience an accident, be it Christians or Muslims, other residents would visit the individuals in need.

Each religion has good principles, because every religion teaches goodness and respects of other religions. It is the people who adhere to their religions who sometimes do not understand their religious teachings properly or seriously, so that onflicts between religious believers still occur. Each religion has its own principles, and has their own perspectives in understanding religious pluralism. In this section the author explains the religious pluralism from perspective of Muslim and Christian in the Kampung Sawah community.

In the view of the Muslims of Kampung Sawah, Religion certainly teaches tolerance towards other religions. That is what is taught in Islam. The people of Kampung Sawah are predominantly Muslim compared to Protestantism and Catholicism. However, being a majority does not mean that Muslims in the Kampung Sawah community act to monopolize religion. It is because in addition to their understanding on Islamic teaching, the Muslim community also adhere to the word of Allah as stated in Surah Al-kafirun verse 6.

Therefore, it can be understood that Islam highly upholds a positive sense of pluralism in tolerating religious adherents. As stated by several 
Islamic religious leaders in Kampung Sawah, they have different religions but there have never been any conflicts. Because both Muslims and Christians have tolerant attitude towards each other and towards other cultures and religions.

Islam as a perfect religion not only teaches its adherents to live harmoniously among fellow Muslims. It also promotes to love and respect to all human. In Islam, it is not allowed to disturb each other and to force each other to embrace a religion. If these teachings carried out properly, religious harmony will happen.

Meanwhile, pluralism in Christianity in Kampung Sawah is also in line with other religions. Their religious leaders or figures urge their congregations to live side by side with other religious communities. In this way, religious harmony and conducive environment will happen without any problems. Interview with Mr. R. Jacob Napiun (Christian leader) revealed that there have been no disputes between community members in Kampung Sawah, which originated on religious issues. Because the Christian teaching itself emphasizes the importance of spreading love. Thus, committed Christians lives must be full of love.

The love in Christian can be proved by living side by side and without conflict with other religious communities. The life of Christians is like testifying or showing religious teachings through their behavior in everyday life. This teaching is carried out during the general worship (persekutuan umum) on Sundays, the fellowship on other days, and in Sunday school for children.

The plurality that appears in Kampung Sawah is not only limited to the social life, but also at the family. Pluralism in Kampung Sawah grew out of family history. In YN family, for instance, there are three religions which are Buddhism, Islam, and Christianity. The condition of this family is like other families where there is only one religion. The relationship between the father with his wife, children, and other family members is harmonious and intimate. This family realizes that religion is a individual's human right so that they cannot force their religion or belief to others. They respect each other. Regarding plularism in his family, YN told that his ancestors were Buddhist, his wife and children were Muslim, but now the children choose Christianity. These choices are made based on individual awareness without any coercion.

Even though there is a plurality of religions in the family, the socializations of cultural values or other values that apply in society are 
continued. This family is aware that despite religious differences, communication between family members must continue. One of them is by means of socialization to children. The socialization that occurs in the YN family is carried out by giving advice and giving exemplary behavior. This means that before the father or other family members ask or suggest to family members to do something, the parents must first do what is being ordered. For example, if parents tell their children to be diligent in worshiping, first, the parents must be diligent in worshiping.

Basically, the YN family accepts religious differences in the family and respects the human rights of family members. This mutual respect is manifested by not forcing any family members to embrace one religion. The harmony can also be seen when one family member celebrating his/her religious day. In this moment, family members of different religions would join to helping. It happens because they believe that religion is a personal matter and an invidual's choice, so no one can force them to embrace a certain religion.

Another example of pluralism in family also occurs in RKN and MS family. The couple, who have been married for 51 years, also have families of different religions. Even though there are religious differences in the family, the relationship among family members runs harmoniously without any problems, especially the problems that originate on differences in beliefs or religions. YKN married MS on September 21, 1967. This family is blessed with 9 children. Five children are Catholic, and four are Muslim. They all live together in peace in one house.

They both acknowledge and respect beliefs held by their children. Engkar or MS have never forced their children to follow their path of becoming a Muslim. She respects her children's decision to choose a different path from her. In fact, they never differentiated their children based on the childrens' religions. YKN explained that even though the children are of different religions, they are still harmonious and respect each other.

The example of the families above shows that, despite differences in their family members' religion, the relationship within each family is harmonious because all members of families respect and tolerate each other both in words and practice. This tolerant attitude is shown when a member of a family of different religion celebrates and organize religious worship. For example, family members in Mr Engkar family will supporting each other when one or more of their familiy members perform worship or 
celebrating religous days. Another example, in MS family, when MS (Muslim) was fasting, her husband will help to prepare the food for breakfasting and sahur and other family members of different religions would respect her by not eating or drinking in front her.

Religious plurality and harmony have become an inherent part of the people of Kampung Sawah. Citizens respect each other and maintain each other's attitudes or words so that there is no conflict between religious communities. The attitudes and words of community members are shown in the attitude of not imposing a religion and in the practice of mutual respect between religious believers. When adherents of a religion celebrate religious holidays, adherents of other religions also congraculate them and and help to make the celebration run smoothly. Likewise, in the family, they also help each other. If there is a family member of different religion celebrate a religious day, other familiy members will help to prepare everything so that the family member can commemorate the big day of their religion.

\section{The Model of Pluralistic Da'wah in Kampung Sawah}

As pointed out above, da'wah in a religiously pluralistic society quite difficult to do. Difficult in the sense that it is not impossible to do, but need to be done by particular approach. At least, a preacher has to contextualize his da'wah into the pluralistic context of the community. The preacher must understand exactly which one is "free space" and which one is "limited space". By understanding this, one can avoid and minimize conflicts resulting from preaching of the two religions.

What is needed is a particular da'wah model for a pluralistic society. The da'wah model that emphasizes humanist approach and touching sociohumanity aspects, such as raising issues of poverty, unemployment, socioculture (divorce, teenagers delinquency), and religion (religious conflict). In other words, the preaching carried out must lead to a model of preaching that is wise, transparent, and inclusive, not exclusive.

Based on the description above, it can be explained that the da'wah model being practiced in Kampung Sawah is: first, a wise model of da'wah. A wise da'wah model is a model of preaching that is carried out by preachers by promoting wisdom, maturity, and understanding of the context of the area (object) of the da'wah. Preaching does not mean to blaspheme, spread hatred, slander, and discriminate one group or community. Wise da'wah is a model of preaching that embraces all groups 
of people even though there are religious differences in it. It also creates mutual understanding between religious believers so that religious tolerance (harmony and togetherness) is created. The wisdom in preaching has also been conveyed by Rosidi (2013: 481) who describes it as multicultural da'wah, a da'wah that respects differences and fights for the cultural rights of each individual.

The preachers (ustad, kiai, ajengan and other community leaders) have shown the model of preaching with a wise attitude. The preachers of both Islam and Christianity, each in their lecture material at mosques or churches, always prioritize the material of tolerance and togetherness. They greatly avoided ridicule, hatred, and suspicion. Gradually this kind of preaching took root in the people of Kampung Sawah, Bekasi City. In this way, tolerance attitude grew in all community members of Kampung Sawah.

The manifestation of tolerant attitude in each individual is shown by the way in which they highly uphold an attitude of respect, appreciation, acknowledgment and not to ridicule each other and not propagate negative sentiments between religious communities. Each of preacher of the two religion feel convenient when carrying out their preaching. The sound of the call to prayer, the church bell, echoes each other without any sense of being disturbed. Interview with DN (a Christian leader) revealed that so far he has lived in Kampung Sawah, there were no Muslim disturbed him by threats, intimidation, coercion or by others way. They really respect the preaching being carried out by other religious preachers. When there is a religious recitation of Islam, and its preacher speak through loudspeaker, Christians do not feel disturbed too.

When Muslims perform prayer, the volume of the adzan is just ordinary. During the fasting month, there is no tradition of waking up other Muslim by loud voice for saur. During tarawih and tadarus prayers there are no excessive loudspeakers and the activities finished at 22.00. Even when there is a resident pass away, regardless of her/his the religion, the people will visit the family and help as much as possible for the family left behind. When a Muslim dies, while a tahlilan being held, non-Muslims would wait outside the house. Once the event is over, they would join in tasting dishes or in conversation. The same thing happens when nonmuslim residents pass away, Muslims will visit, and wait patiently while the family held ritual it is over.

This wise model of da'wah has long been practiced by the people of 
Kampung Sawah. It makes the people of Kampung Sawah really uphold tolerance among them. One example is when religious holidays come, such as Idul Fitri or Christmas. It would be difficult to distinguish between Muslims and Christians. All of them mingle with each other to visit friends, close family, and neighbors, which is a common thing (normal) for the people of Kampung sawah during these religious holidays.

Second, the transformative da'wah model that is the preaching model of humanity that emphasizes social values. The model bring about aspects of social change that are more just, humane, and egalitarian. It may refer to contemporary da'wah. The Da'wah that calls for the liberation of mankind. As a liberation practice, this model of preaching aims to transform Islamic teachings into a social act. So the practice of da'wah must aim to free mankind from the process of ignorance, impoverishment, and injustice. As a form of liberation, the preachers should invite religious followers to fight together, freeing themselves from various social problems, such as poverty, social injustice problems, and humanitarian problems.

The transformative da'wah model carried out by the preachers in Kampung Sawah by strengthening the community's socio-cultural system. At this stage, the preachers of the two religions, both Islam and Christianity, blend into one in social-community activities. Each of the preachers taught about humanity and togetherness. This means that religious community would unite once what is emphasized in religious teachings are the values of togetherness in religion, namely humanity.

The approach through the social system is practiced by the preachers of the two religions through social activities that involve all religious members (Islam, Protestant Christianity and Catholic Christianity) and ethnicity without any discrimination. While the cultural systems is a preaching that promotes social, cultural, and religious values. The author sees that the people of Kampung Sawah have common and shared values on which they are concerned. Some examples of these values are helping each other and helping fellow residents affected by disasters, helping each other, patrolling (ronda), and life cycle ceremonies (birth-marriage-death).

The transformative da'wah would be more meaniful by building a spirit of togetherness. According to Arib (2014: 35) togetherness in social interests that can be the glue of pluralism so that it can minimize horizontal conflicts between religious adherents. With this transformative da'wah practice in Kampung Sawah, the community grew into a tolerant society 
and actively participated in joint development.

Third, the inclusive da'wah model that is the wisdom da'wah model. This model views that anyone in this life is part of us. With this viewpoint, da'wah can act as an effective mediator to unite the divided people. The da'wah would also be able to stimulate a sense of brotherhood among fellow humans, regardless of ethnic or religious differences. This is because Islam does not teach its people to think one-sidedly and exclusively about Muslims and all human being.

An inclusive da'wah has a tendency to promote dialogue with other religions in communities (Mulyana, 2005: 81). By means of dialogue, there is a sign of the ability to understand the language of the dialogue partner. So that "language" is not only limited to a medium of communication, but must be understood further as a way to connect with desires, aspirations, hopes, interests, ideals, fears, worries felt by dialogue partners. Dialogue has to be at the core of communication and human existence. Dialogue talk about "I-You" (Saya-Anda) that is between human and human characterized by togetherness, open-heartedness, continuity, honesty, spontaneity, straightforwardness, non-manipulative, harmony, intensity, and love in the sense of being responsible to others.

The preachers should be able to enter a community through this dialogue. Through dialogue between preachers of different religions, they will understand their respective religious truths. This is what is called inclusive preaching, that their religion is open to accepting dialogue with other religions. Dialogue provides an opportunity for each religious adherents to maintain that their religion is the most correct one. The most important basis for this inclusive da'wah model is to uphold pluralism.

The inclusive dakwah model has been implemented in Kampung Sawah, Bekasi City. Preachers from Islam, Catholic Christianity, and Protestant Christianity mingle into one. Community leaders, as well as community elders in Kampung Sawah, mingled into one with the local community. They gather to have a dialogue. Inclusive dakwah model through dialogue has been carried out since 2011. The aim is to provide insights to the public about what religious tolerance is, so that there will be an attitude of mutual respect for togetherness and mutual love among them.

The figures who attended this tolerance dialogue event came from various circles. Preachers from the two religions (kiai, ustad, ajengan, priests and others), as well as academics, bureaucrats, pesantren, cultural 
observers (budayawan) and politicians, including GN, YP, AA, SK, KH. $\mathrm{RA}$, and others were involved. The material presented was related to the idea of building peaceful tolerance, togetherness, and mutual respect in Kampung sawah.

Furthermore, the interview results also show the idea of plurality with nature. If nature is properly understood, then God basically wants the world to be plural, diverse. The are many examples. When manoculture is enforced, the plants will quickly become attacked by pests and many diseases. Beauty does not materialize without diversity in its elements. Furthermore, it is also discussed about two levels of human achievement related to respect for differences or plurality. First is recognition (recognition ethics), that we recognize ourselves as different from others, and acknowledge differences of others. The second is openness, being open to other people who are different. This is the next stage after recognition. Being open means willing to accept different views and also opening up the possibility of oneself being changed and shaped through encounters with other people.

GN applies the philosophical construction of natural plurality. With a straightforward style and rich metaphor, he said that this nation already has everything formal but at the same time loses wisdom or spirit. So what happens is hypocrisy, selfishness, feeling the truest, even though in fact they do not understand the root of the problem and do not have deep (religious) knowledge. The concept that GN wants to develop is "Garden of the Heart" (Taman Hati). A garden is a place where anything can and should live, from the dirty to the beautiful. That is plurality. The heart is a place where humans can weigh up what is good. It was added that our leader may have a heart, but no conscience anymore. An interesting metaphor is, if the Medina Charter was made as a written basis for a tolerant life, in Kampung Sawah it was not written down but it has been practiced.

The results of the interview with RA underlined the need for unity. He gave the term PKB (Pastor Kyai Bersatu). How wonderful it would be if everyone could stand together and say that what was being done was for the sake of our beloved Indonesia Raya. The most interesting thing for me was the appeal he made as the Chairperson of the Pondok Melati MUI for tolerance, not to slander other people and their teachings, the prohibition of selling alcohol, community study hours, and others. For me personally, this is something advanced compared to the Central MUI, which is more diligent in issuing fatwas than appeals for something that are more 
beneficial for society.

He also emphasized his commitment to defend the land of Kampung Sawah, which historically has already been plural and peaceful. Thus, inclusive da'wah is a da'wah model that promotes religious plurality. Plurality is a necessity and in the same time is part of the mission of da'wah. This means that preaching with religious pluralism suggests that every religious adherent is required not only to recognize the existence and rights of other religions, but to be involved in efforts to understand differences and similarities between them in order to achieve harmony in diversity.

Furthermore, Nawawi (2012) provided an explanation of inclusive da'wah which he calls multicultural da'wah. One of the characteristics of inclusive da'wah in Nawawi's point of view is material content of the da'wah that focuses on universal values. While the approach used is the socio-cultural approach. Inclusive da'wah is a mission that tries to draw all the values of the universality of religion into a single goal of the common good by avoiding conflict. This is also motivated by the fundamental perception of human existence which is seen as an entity that has a good nature (fitrah kebaikan). In fact, all religions teach about maintaining love, doing good to others, and guaranteeing each other's rights.

\section{Creating Community Harmony in Kampung Sawah}

As explained earlier, the people of Kampung Sawah are known as the golden triangle kampong (kampung segi tiga emas), because they have three religions that co-exists side by side (Islam, Catholicism and Protestanism). Even though resident of the Kampung live side by side with other risidents from different religions, all residents of Kampung sawah are known to be very tolerant people. They have high mutual respect. This is a result of the preaching carried out by religious leaders, both Islam (ajengan, kiai and ustad) and Christianity (pastors) who put forward the preaching of wisdom, transformative preaching and, inclusive preaching in the community. This section will describe how the community responds to the preaching carried out by preachers of each religion. It will also describe the response of the Christian community (Protestant and Catholic) to the preaching carried out by Muslims, and vice versa.

One of the parameters to measure the response of da'wah is religious attitude between the believers from Islam and Christianity or a person's attitude towards others. This means the attitudes towards the preaching of other people of different religions; for example the attitude of Christian 
community (Protestants and Catholics) towards preaching from the Muslim community, and vice versa. In Paloutzian's theory (1996: 200), the attitude referred to is the presence or absence of prejudice that a religious person has against other religious groups. This prejudice can take the form of affect--the feeling that arises (happy or displeased); Behavior--behavior that follows the feeling (approaching or avoiding), and cognition--an assessment of the object of attitude (good or bad).

The people of Kampung Sawah from different religious background to which transformative preaching has been carried out do not see other people only on the physical or the outside side of something or someone. In fact, external symbols often deceiving. They are more concerned with the essence or content, rather than the symbols that are often tricky. The author sees that the way they belive in and practing religion seems to be more mature, because their point of view is no longer dichotomous (good or bad and profit or loss), but more concern on human values, togetherness, and mutual respect. This is a reflection of the success of the transformative da'wah model promoted by preachers of the two religions which prioritizes human values that in turn also create high tolerance attitude.

The people of Kampung Sawah tend to be tolerant to preaching from people of different religions. For the people of Kampung Sawah, as long as other people's religions teach goodness and do not harm their religion (e.g. Islam), they should be respected. The tendency of the Kampung Sawah community's attitude lead to an inclusive and even pluralist attitude in religion. This inclusive attitude has also become a da'wah model promoted by the two religions. What is shown is their courage to declaring openness in religion, seeing similarities between religions rather than sharpening differences. In the inclusive Islamic paradigm, openness to dialogue between faiths is based on the spirit of finding the Sawa sentence (kalimatun sawa) which is indicated in the Q.S. Ali 'Imran (3): 64.

One of proofs that the people of Kampung Sawah carry inclusive and pluralist preaching is that they accept the differences. Many religions have grown and developed in Kampung Sawah. Islam and Christianity are almost proportional in terms of the number of places of worship and their adherents. Yet, until now there has never been a friction that caused conflict between them. As explained by a religious leader, Rahmadin Afif, Kampung Sawah has a spirit of brotherhood. This is seen as an indicator of the success of the preaching carried out in the area. Da'wah in Kampung 
Sawah carries wise preaching (not hate each other), transformative preaching (social and human values), and inclusive preaching (openness). Through this da'wah model, one can learn the meaning of living in harmony and tolerance in a diverse religious communities.

This kampung is known as the kampung of brotherhood and has even become an icon of the value of tolerance for Bekasi City citizens. Kampung sawah has 13 churches and 18 mosques. The community respects each other. Even the Mayor of Bekasi appreciated Kampung Sawah and took the initiative to make Kampung Sawah as a Pancasila kampung due to the religious harmony among the diverse residents.

It is understood that stereotypes, prejudice, and ethnocentrism are potential obstacles in intercultural communication. If these stereotypes, prejudices, and ethnocentrism have negative dimensions, they will potentially disrupt the communication and interaction of different religious groups. However, the ethnocentrism of the people of Kampung Sawah, who are Muslims, towards the preaching carried out by other religions (Catholicism and Protestantanism) and vice versa, has rather a positive dimension. This means that in their interactions, there are no groups who have attitudes that only their norms, religion, values, and behavior that are good, while the group (other people) is ugly, incorrect, and insignificant.

These attitudes can be seen when they gather and interact with each other. The topic in their daily chats between Muslims and Christians in the Kampung Sawah are general themes, such as social issues, health, work, marriage, circumcision, death, and other family problems. The way they responding each other in interaction are the typical Betawi expression of Kampung Sawah which characterized by frank tone, full of jokes and laughter, even though sometimes the responses given are not appropriate or not in accordance with the context of the conversation. This cannot be separated from the preaching model that has been built among the community. Pluralistic da'wah has formed a religious understanding of each citizen towards his/her religious teachings. They believe that all religions teach goodness, everyone is free to embrace any religion, and no blaspheme and hatred are allowed.

The da'wah model above has created the awareness of the people of Kampung Sawah about the existence of religious differences. Finally, they try to understand and respect other people of different religions, because there is an understanding that all religions teach the same thing, only different ways of worship. This awareness also eventually creates a high 
sense of solidarity. This means that between Muslims and Christians they need each other and need to work together. So that the ego of each (due to religious differences) disappears by itself. What emerges is the value of togetherness and harmony.

Solidarity between residents of different religions in the community of Kampung Sawah is also shown by helping neighbors who experience disaster by not observing the status of their religion. Each resident has the awareness to help ease the burden of others. If one of the residents of Kampung sawah is sick and is hospitalized, other residents will collect money for the sick resident.

In every dakwah movement, there must be challenges and obstacles. The da'wah movement in Kampung Sawah is not an exception. Every religion, both Islam and Christianity (Potestant and Catholic), has the term preaching, although in different forms. Preaching is an effort to socialize (invite or call for) religious teachings. Accordingly, every religion will teach or justify that its religion is the most correct.

The statement and invitation are not wrong. But if these interests are put forward, each religion will potentially confronting each other to uphold the truth that may trigger religious sentiment. So it is not impossible that a clash happens and led to conflict between religions. This problem is not imposible to occur in Kampung Sawah. Starting from the awareness of each religious figure and community elders, it is necessary to preach peacefully and does not cause upheaval and unrest in the community. In this regards, for the people of Kampung Sawah, a different model of da'wah is needed that is a preaching that not harsh, violent, and uncompromising. Furthermore, it must present a model of preaching that is cool, no hatred (wisdom), and promotes togetherness (transformative) and upholds openness (inclusion).

The mission of the da'wah model above is to create harmony, tolerance, and togetherness. This can be created by first, avoiding conflict. Conflict must be avoided in any form. This is a joint commitment between preachers in Kampung Sawah. This commitment is manifested in the mission of each religion being preached. The main mission of preaching is to look for similarities not differences. The meeting point of these similarities is in the common value of humanity. Talking about humanity is talking about "we", not "me". Talking "we" is talking together and togetherness. The suitable themes to be carried out for this, threfore, are social, brotherhood, economy, and culture. With such themes, conflicts 
between people will be avoided. It surely requires awareness from each member of the community. The way to raise this awareness is none other than the task of preachers of each religion. That way, it is important to build similarity perceptions among preachers, so that the goals and objectives can be easily achieved.

The same approach is done by residents of Patoman Banyuwangi Village, to manage diversity so that it does not become conflict. The community and religious leaders in this village build awareness about the importance of focusing their attetion on their respective personal beliefs by not discussing anything that potentially causing conflict. By limiting themselves from discussing sensitive issues, it is hoped that the community can get appreciation for their respective beliefs, so that their energy can be focused on collaborating in positive things (Wicaksono, Yudian \& Wahyudiono 2019: 174).

Second, Helping Each Other Despite Different Religions. The attitude of mutual cooperation and mutual assistance has been the basis of the life of the people of Kampung Sawah, since a long time ago. This attitude has been transmitted from generation to generation until now, so that it is still manifested in the activities of the community. The people of Kampung Sawah, in their daily lives, always help each other, despite religious differences, so conflicts can be easily avoided. One of forms of their mutual assistance is in life cycles such as birth, marriage, and death. The three life cycles will be experienced throughout the ages. If there is a woman give birth, other residents will help by giving donations and energy. Likewise, when there are people who celebrate marriage or when a member of community pass away, without being asked, the community will help voluntarily. It happens regardless religious background of the individuals.

Gotong royong or mutual cooperation is the term that allows every element of diversity in a place to be recognized for its existence. This concept also makes pluralism flourish. Furthermore, mutual cooperation is a manifestation of equal opportunity for all member of communities to actively contribute in the name of universal values. This was a President Soekarno's big idea, the terminology of gotong royong or mutual cooperation is a positive reflection of the diversity and plurality of Indonesian society (Dewantara, 2015: 119).

Third. Holding Inter-Religious Dialogue. To strengthen harmony between religious communities, dialogue between religious communities will continue. The dialogue between people in Kampung Sawah was first 
held in 2000 and continues today. The theme it carries is Inter-Religious Tolerance. The dialogue attended by speakers from the central government and the City of Bekasi, with representatives from Islam, Hinduism, Protestant Christianity, Catholic Christianity and Buddhism. The local government is very supportive of the inter-religious dialogue, by facilitating all that is needed. This dialogue aims to build awareness that there are beliefs in other people and other cultures that we must recognize and respect.

Fourth, Mutual Cooperation (Gotong Royong). Another form of effort to create harmony and tolerance is to carry out mutual cooperation (gotong royong). Implementing mutual cooperation has become a collective agreement. For example, doing scheduled siskamling in order to collectively maintain the security of the village. In such a situation, harmony between religious communities in Kampung Sawah can be seen clearly. During the field work, researcher observed ongoing gotong royong and cooperation in one of the community members of Kampung Sawah. This mutual cooperation involved Muslims and Christians. The mutual cooperation they did was cleaning the village such as cleaning the gutters, helping each other if someone is moving to a new location, working together in planning Independence day event, and helping each other when one of the religious communities held an event or ceremony.

Fifth. Forum "Ngeriung Bareng" (Gathering Forum). One of the keys to create high tolerance and low religious conflict in Kampung Sawah is the implementation of the concept of "Ngeriung Bareng" or gathering together. This event was organized in the framework of uniting perceptions and goals, so as not to have misperceptions of each other that may lead to conflict. In "Ngeriung Bareng", community figures, religious leaders, youth and other community elites gather together to discuss various matters related to problems in the community of Kampung Sawah. The goal is that all people will realize and understand once a problem occurs so that it can be solved together.

This concept was initiated because people of Kampung Sawah realized that they are very pluralist. Usually pluralist societies are very vulnerable to differences. "Ngeriung Bareng" is held in order to unite the differences between these different communities and get the communities closer. With this concept, Kampung Sawah can always resolve interfaith conflicts that may arise in their area. From the concept of "ngariung bareng", the term "Empat Nyok" (Four Let's) also emerges. The term is 
basically a mutual agreement to protect the village together.

The "ngeriung bareng" forum was formed on January 1, 2009. This event originated from the idea of a past conversation that was so beautiful, harmonious, and typical of Kampung Sawah. This event was attended by interfaith groups in Kampung Sawah (Muslim, Catholic and Protestant), such as community leaders Yakobus Napiun, KH. Rahmadin Afif (Ponpes Fi Sabilillah), Father Sarto (Christian figure), Ustadz Malik, Ustadz Arifin, Pasundan Church Majlis officials, Hindu religious leaders, Chairman of RW 02, head of Jatimurni village, sub-district, and DPRD members. The purpose of this event is to create harmony between religious communities in Kampung Sawah. This event gave birth to a unique joint pledge of Kampung Sawah called "Empat Nyok" (Four Let's), with the Betawi language accent of Kampung Sawah. First, Nyo (let's) 'preserve the Betawi culture of Kampung Sawah. Second, Nyo (let's) keep our village green. Third, Nyo (let's) "empower the people of Kampung Sawah to remain peaceful, prosperous and harmonious. Fourth, Nyo (let's) "keep our community clean and healtby.

When the pledge was finished, a number of interfaith leaders signed a joint pledge, which was followed by the release of a dove as a symbol of freedom and harmony, and planting a klengkeng tree as a symbol of "we cannot live alone" like the klengkeng tree. These steps are seen as important effort to maintain harmony. With various da'wah activities that do not eliminate the importance of diversity, the community is expected to respect each other's existence (Alifuddin, 2015: 189).

\section{CONCLUSION}

The people of Kampung Sawah are known as a pluralistic society in terms of religion. The plurality of religions in Kampung Sawah is shown by the existence of various places of worship. There are Islam, Catholicism, and Protestanism. Only a small proportion of Hindus and Buddhists. In addition to the many number of worship building, the population composition is also balanced between these religions. Despite having different religions, Kampung Sawah is also known as a very harmonious and tolerant community. They highly value equality not difference. This is manifested in the daily life of the people of Kampung Sawah, such as cooperation (gotong royong), mutual help, and other social attitudes.

The growing and high attitudes of harmony and tolerance do not stand alone. The very important role in creating such attitudes is the preaching carried out by local religious leaders. The process of preaching 
has led to high public awareness of the importance of maintaining unity and togetherness in religious differences. The preaching that has been done has led the public to an established perspective on pluralism, awareness to respect the existence of adherents of other religions with a spirit of brotherhood.

The da'wah being carried out in Kampung Sawah is different from the preaching as it usually being done in other places. It is a pluralistic preaching or preaching in the heterogeneity of society in religion. In this situation, we need a distinct da'wah model. The emergence of a good religious attitude among the people of Kampung Sawah is a manifestation of the success of the preaching. Da'wah model that has been carried out consists of three model. First, a wise da'wah model (peaceful preaching without hatred); second, a transformative da'wah model (one that promotes togetherness); third, inclusive da'wah model (upholding openness).

To maintain harmony, the people of Kampung Sawah and their religious leaders consistently take concrete steps. The steps include establishing a commitment to avoid conflict, helping each other, even though they have different religions. Another important step is consistently opening spaces for dialogue, building awareness of the importance of cooperation (gotong royong), and finally holding the "Ngeriung Bareng" Forum, an event that was deliberately initiated to open spaces for interaction between the citizens.

The fact that Kampung Sawah is an area inhabited by plural communities, but is still able to maintain harmony, is a positive thing for national life and development. Da'wah models that carry the universality of values are important in modern da'wah activities. The da'wah model that has been applied by the religious leaders of Kampung Sawah can be an empirical reference in the development of multicultural da'wah in other places.

\section{REFERENCES}

Abdullah, M. Q., \& Mubara D. F. (2019) Dakwah Dalam Merawat Pluralitas di Kalangan Remaja, Anida (Aktualisasi Nuansa Ilmu Dakwah), 19(2) 177-197. https://doi.org/10.15575/anida.v19i2.7589 Alifuddin, M. (2015). Dakwah Inklusif dalam Masyarakat Segregatif di Aoma dan Ambesakoa Sulawesi Tenggara, Jurnal Dakwah; Media Komunikasi dan Dakwah. 16(2). 171-201. https://doi.org/10.14421/jd.2015.16201 
Deden Sumpena \& Adon Nasurullah

Arib, M. (2014). Dakwah di Tengah Keragaman dan Perbedaan, Jurnal Dakwah Tabligh, $15 \quad$ (1), 35-49. https://doi.org/10.24252/jdt.v15i1.337

Asy'ari, S. I, (1993). Sosiologi Kota dan Desa. Surabaya: Usaha Nasional.

Dewantara, W. D. (2015). Pancasila dan Multikulturalisme Indoensia, Jurnal Studia Philosophica et Theologica, 15(2) 109-126 https://doi.org/10.35312/spet.v15i2.53

Huda, Z. (2016). Dakwah Islam Multikultural (Metode Dakwah Nabi SAW Kepada Umat Agama Lain), Jurnal Religia, 19 (1), 89-112. https://doi.org/10.28918/religia.v19i1.661

Mulyana, D. (2005). Nuansa-nuansa komunikasi, Meneropong Politik dan Budaya Komunikasi Masyarakat Kontemporer. Bandung: PT Remaja Rosdakarya.

Nawawi. (2012). Dakwah Dalam Masyarakat Multikultural, Jurnal Komunika 6(1).

http://ejournal.iainpurwokerto.ac.id/index.php/komunika/arti cle/view/347

Paloutzian, R. F. (1996). Invitation to Psychology of Religion. Boston: Allyn \& Bacon.

Praptanto, A. E., (2011). Sepangkeng Kisah Gereja Katolik Kampung Sawah. Kota Bekasi: Paroki Servatius Kampung Sawah.

Rosidi. (2013) Dakwah Multikultural Di Indonesia : Studi Pemikiran dan Gerakan Dakwah Abdurrahman, Analisis; Jurnal Studi Keislaman. 13(2), 418-499. https://doi.org/10.24042/ajsk.v13i2.708

Soemardjan, S., \& Soelaeman, S. (1974). Setangkai Bunga Sosiologi. Jakarta: LPFE-UI.

Suwarsono. (2006). Perubahan Sosial dan Pembangunan. Jakarta: LP3ES.

Wibisono, M. Y. (2016) Pluralisme Agama dan Perubahan Sosial dalam Perspektif Islam, Religious: Jumal Agama dan Lintas Budaya. 1(1). 12-24. https://journal.uinsgd.ac.id/index.php/Religious

Wicaksono, D. B., Yudiana, I. K., \& Wahyudiono, A. (2019) Analisis NilaiNilai Multikultural Masyarakat Desa Patoman, Blimbingsari, Banyuwangi, Jumal Pendidikan Sejarah Indonesia, 2(2), 164-178 http://dx.doi.org/10.17977/um033v2i22019p164. 